\title{
TAISNĪGUMA NOZĪME TIESISKĀS IEKĀRTAS PĀRVEIDOŠANĀ
}

\section{ROLE OF JUSTICE IN TRANSFORMING THE LEGAL SYSTEM}

\section{Elīna Grigore-Bāra, Dr. iur.}

Latvijas Universitātes Juridiskās fakultātes

Tiesību teorijas un vēstures zinātṇu katedras docente

\section{Summary}

The author analyses the transformation of the Latvian legal system since May 4, 1990, examining the purpose of these reforms, their basic principles and their impact on the application of rights, paying particular attention to the characteristics of understanding of justice under the conditions of significant and fundamental legal transformations.

The transformation of the Latvian legal system after restoration of independence was a transition from a communist totalitarian regime to a democratic system, and should be considered in the context of transitional justice. Mechanisms of transitional justice are temporary, must be viewed dynamically and should be implement as a coherent system. The author argues that the courts should also engage in the effective implementation of mechanisms for overcoming the past. Consequently, the concept of transitional justice must also be taken into account in the application of law when interpreting legal norms (within the framework of systemic or teleological interpretation) and in dealing with conflicts of fundamental rights.

Atslēgvārdi: pārejas taisnīgums, vēstures pārvarēšana, reabilitācija, Latvijas Republikas neatkarības atjaunošana, valsts nepārtrauktības doktrīna

Keywords: transitional justice, overcoming the past, rehabilitation, restoration of independence of the Republic of Latvia, doctrine of state continuity

\section{Ievads}

Tiesiskās iekārtas pārveidošana jeb transformācija šajā rakstā jāskata kontekstā ar valsts rašanās un izbeigšanās jautājumiem. 1990. gada 4. maijā notika derivatīva jeb atvasināta (sekundāra) vienas valsts izbeigšanās un citas valsts rašanās. Georgs Jellineks (Georg Jellinek) skaidrojis, ka valsts izcelšanās un izbeigšanās ir fakta un nevis tiesību jautājums. ${ }^{1}$ Tātad uz šādu "valsts nomaiṇu" mēs nevaram attiecināt legālus jeb likumīgus kritērijus. "Valsts nomaiṇa" vienlaikus ir arī revolūcija būtiska tiesiskās iekārtas pamatstruktūru pārveidošana² vai valsts formas maiṇa. ${ }^{3}$

Jellinek G. Allgemeine Staatslehre. 3. Aufl. Berlin, Zürich: Verlag Dr. Max Gehlen, 1966, S. 283.

Cipeliuss R. Vispārējā mācība par valsti. Rīga: AGB, 1998, 112. lpp.

3 Schöbener B., Knauff M. Allgemeine Staatslehre. 2. Aufl. München: Verlag C. H. Beck, 2013, S. 155. 
Revolūcijas tiesisko kvalifikāciju nosaka tās faktiskie panākumi. Ja tā neizdodas, tad revolucionārās darbības kḷūst krimināli sodāmas atbilstoši iepriekšejās valsts likumiem. Savukārt sekmīgas revolūcijas iegūst konstitucionāli tiesisku nozīmi jaunajā valstī. Izdevusies revolūcija rada ne tikai jaunu varas stāvokli, bet arī jaunu tiesisko situāciju. Tomēr arī ārpus likuma notiekošiem procesiem ir nepieciešams attaisnojums, kas šiem procesiem piešksir jēgu, pamato to nepieciešamību un nozīmību. Tāpēc arī revolūcijas kontekstā tiek runāts par legalitātes un legitimitātes problēmu. Katra revolūcija balstās uz kādu politisko mērḳi un ideju, kas to attaisno jeb legitimē. Tiesību filozofijā vairākas vērtības tiek atzìtas par pietiekamu attaisnojumu, lai pretotos valsts varai - vispirms jau taisnīgums, kā arī brīvìbas, dzīvības un īpašuma aizsardzība. Tātad jebkuras tiesiskās iekārtas pārveidošana nedrīkst būt patvaḷịga, bet tai ir jāievēro šìs transformācijas mērķis. Šì raksta mērķis ir analizēt Latvijas tiesiskās sistēmas transformāciju kopš 1990. gada 4. maija, izpētot šo pārkārtojumu mērḳi, pamatprincipus un to ietekmi uz tiesību piemērošanu, sevišķu uzmanību veltot taisnīguma izpratnes īpatnībām plašu un fundamentālu tiesisku pārkārtojumu apstākḷos.

\section{Latvijas tiesiskās iekārtas pārveidošana valsts nepārtrauktības doktrīnas kontekstā}

Latviešu nācijas politiskais mērķis 1990. gadā bija valstiskā neatkarība - brīvība. Jāuzsver, ka brīvības atgūšana nevar tikt uzskatīta par politisku pašmērķi. Tā ir nepieciešams priekšnoteikums taisnīgas tiesiskās iekārtas izveidei, kurā ir radīti optimāli priekšnosacījumi katra indivīda laimes sasniegšanai. Latvijas valstisko neatkarību teorētiski varēja sasniegt divējādi - atjaunojot 1918. gadā dibināto Latvijas Republiku vai arī īstenojot tautas pašnoteikšanās tiesības un dibinot jaunu valsti. ${ }^{4} \mathrm{Ka}$ zināms, tika izvēlēts pirmais variants un Latvijas Republika tika atjaunota uz valsts nepārtrauktības doktrīnas pamata. Latvijas konstitucionālajā iekārtā valstiskā nepārtrauktība ir noteikta kā konstitucionāla ranga norma, kas prasa noteiktu valsts rīcības modeli, pārvarot PSRS okupācijas sekas un nostiprinot savu valstiskumu. ${ }^{5}$

Valstiskās nepārtrauktības doktrīnas kontekstā jāvērtē taisnīguma princips un tā nozīme turpmākajos tiesiskās iekārtas pārveidojumos. Taisnīgums jau bija konkretizēts Latvijas Republikas likumos. Satversmē noteiktā valsts institucionālā uzbūve bija prezumējama kā taisnīga un leg̣itīma. Līdz ar to likumdevēja rīcības brīvība bija ierobežota ar pienākumu rīkoties atbilstoši Latvijas Republikas konstitucionāli tiesiskajiem pamatiem. Savukārt, tā kā valsts nepārtrauktības doktrīna balstās uz atzinumu, ka PSRS kā okupācijas vara ir rīkojusies prettiesiski, likumdevējam bija pienākums veikt pasākumus, lai iespēju robežās izlīdzinātu okupācijas režìma nodarītos zaudējumus un atjaunotu taisnīgumu. ${ }^{6}$ Minētā Satversmes tiesas

4 Levits E. Valsts atjaunošanas koncepcijas attīstība. Grām.: Levits E. Valstsgriba. Rīga: Latvijas Vēstnesis, 2019, 105. lpp.

5 Pleps J. Baltijas valstu valstiskā nepārtrauktība. Grām.: Nepārtrauktības doktrīna Latvijas vēstures kontekstā. Autoru kolektīvs prof. T. Jundža zinātniskā vadībā. Rīga: LZA Baltijas stratēǵisko pētījumu centrs, 2017, 75. lpp.

6 Satversmes tiesas 25.03.2003. spriedums lietā Nr. 2002-1201, secinājumu daḷas 1. punkts. Par likuma "Par zemes reformu Latvijas Republikas pilsētās" 12. panta pirmās daḷas 3. punkta atbilstību Latvijas Republikas Satversmes 1. un 105. pantam. 
atziņa atspoguḷo senu Eiropas tiesību filozofijas taisnīguma izpratni. Aristotelis, skaidrojot taisnīguma jēdzienu, rakstijis, ka taisnīga rīcība ir vidus starp galējībām "darìt netaisnību" un "ciest netaisnību". Netaisnību ciest gan ir mazāks l̦aunums pats par sevi, taču nav neiespējams, ka konkrētā gadījumā šāds stāvoklis var būt lielāks l̦aunums. ${ }^{7}$ Tātad fakts, ka tā nebija Latvijas valsts, kas pastrādāja noziegumus, nenozīmē, ka Latvija varēja svešas valsts varas nodarītos noziegumus vienkārši aizmirst. Šāda aizmiršana būtu netaisnīga rīcība un neatbilstu tiesiskas valsts principam. Tādēḷ arī nevar piekrist politikas zinātnē paustajai atziṇai, ka jaunais demokrātiskais režīms var izlemt: piedot un aizmirst vai arī izmeklēt represīvā režīma pastrādātos noziegumus un sodìt vainīgās amatpersonas. ${ }^{8}$

Lai arī pilnīga norobežošanās no pagātnes nav piel̦aujama ne ētisku, ne tiesisku apsvērumu dēl, valsts bauda plašu rīcības brīvību, izvēloties konkrētus instrumentus iepriekšèjā represīvā režīma rīcības izvērtěšanai. ${ }^{9}$ Tomēr komunistiskās totalitārās sistēmas mantojuma likvidēšanai izvēlētajiem pasākumiem jābūt atbilstīgiem demokrātiskas un tiesiskas valsts principiem un cilvēktiesībām. ${ }^{10}$ Eiropas Cilvēktiesību tiesa ir atzinusi, ka pagātnes pārvarēšanas pasākumu mērķis - pagātnes pieredzes atkārtošanās novēršana un pašaizsargājošas demokrātijas izveide - ir savienojams ar Eiropas Cilvēka tiesību un pamatbrīvību aizsardzības konvencijas tiesību un vispārējo mērḳu principu, proti, valsts neatkarības, tās demokrātiskās iekārtas, institucionālās sistēmas un valsts drošības aizsardzību. ${ }^{11}$ Tomēr izvēlēto pasākumu tiesiskuma vērtējumā izšḳiroša nozīme visbiežāk ir tieši samērīguma principa ievērošanai.

\section{Pārejas taisnīguma jēdziens un tā saturs}

Latvijas tiesiskās iekārtas pārveidošana pēc neatkarības atjaunošanas politiskā ziṇā jāuzlūko kā pāreja no komunistiskā totalitārā režīma uz demokrātisku. Šāda veida pārkārtojumi ir saistīti ar pagātnes netaisnību un noziegumu apzināšanas un izvērtēšanas nepieciešamību un turpmāku tiesiskās iekārtas attīstību nu jau demokrātiskas un tiesiskas valsts principu ietvarā. Šādu politisku un tiesisku transformācijas procesu raksturošanai un izpratnei tiesību zinātnē un politikas teorijā tiek izmantots pārejas taisnīguma jēdziens (angḷu val. - transitional justice). ${ }^{12}$

Apvienoto Nāciju Organizācijā (turpmāk - ANO) jau ilgāku laiku norisinās darbs pie standartu un mehānismu definēšanas un pilnveidošanas, tā mērḳis ir izvērtēt un pārvarēt pagātnē pastrādātos noziegumus, lai izvairìtos no šādu noziegumu atkārtošanās. ${ }^{13}$ Šādā kontekstā ANO sistēmā tiek izmantots pārejas taisnīguma jēdziens - tas tiek skaidrots un attīstīts starptautisko cilvēktiesību, humanitāro tiesību, starptautisko krimināltiesību un starptautisko bēgḷu tiesību ietvaros.

7 Aristotelis. Nikomaha ētika. Rīga: Zvaigzne, 1985, 110., 111., 121. lpp.

8 Ijjabs I. Politikas teorija: pirmie soḷi. Rīga: Lasītava, 2017, 198. lpp.

9 ECT 05.12.2017. lēmums lietā Haralambi Borisov Anchev against Bulgaria (iesnieguma Nr. 38334/08 un 68242/16), 102. punkts.

10 Eiropas Padomes Parlamentārās asamblejas 27.06.1996. rezolūcija 1069(1996). Citēts no: ECT 24.06.2008. spriedums lietā Ādamsons pret Latviju (iesniegums Nr. 3669/03), Latvijas Republikas Ārlietu ministrijas tulkojums, 83. punkts.

11 Ibid., 120. punkts.

12 Teitel R. G. Transitional Justice. New York: Oxford University Press, 2001, p. 3.

13 Ziemele I. Ko darīt ar okupācijas laikā Latvijai nodarītajiem zaudējumiem. Jurista Vārds, 19.01.2016., Nr. 3 (906). 
Kā vienu no galvenajiem pārejas taisnīguma mehānismu ieviešanas uzdevumiem ANO ir definējusi nesodāmības novēršanu. ${ }^{14}$ Tomēr tas nenozīmē, ka pārejas taisnīgums aptvertu tikai kriminālās justīcijas jomu.

ANO generālsekretārs pārejas taisnīgumu definējis kā dažādu procesu un mehānismu kopumu saistībā ar sabiedrības mēginājumiem pārvarēt pagātnē notikušos liela mēroga tiesību pārkāpumus, lai nodrošinātu atbildību, kalpotu taisnīgumam un panāktu izlīgumu. Pārejas taisnīgums var tikt îstenots ar starptautiskās sabiedrības iesaisti vai bez tās, tas aptver kā tiesas, tā arī ārpustiesas mehānismus, kriminālprocesus pret indivīdiem, reparācijas cietušajiem, patiesības noskaidrošanu, institucionālās reformas, tai skaitā arī amatpersonu pārvērtēšanu un atbrìvošanu. ${ }^{15}$

Raksturojot pārejas taisnīguma mehānismus, ANO sevišķi uzsver šādus četrus principus: 1) valsts pienākumu izmeklēt smagus cilvēktiesību un humanitāro tiesību pārkāpumus un sodīt vainīgās personas; 2) tiesības zināt patiesību par pagātnes pārkāpumiem un tiesības uzzināt pazudušo personu likteni; 3) upuru tiesības uz reparācijām par pārciestajiem smagajiem cilvēktiesību un humanitāro tiesību pārkāpumiem; 4) valsts pienākumu, izmantojot visdažādākos līdzekḷus, novērst līdzīgu zvērību atkārtošanos nākotnē. ${ }^{16}$

Būtībā tādus pašus galvenos četrus pārejas taisnīguma politikas virzienus formulējis arī Egils Levits. Viņš skaidroja, ka ikkatram no šiem virzieniem ir savi mērķi, taču tie ir piemērojami vienlaicīgi: 1) vēsturiskās patiesības atklāšana; 2) juridiska izmeklēšana un noziedznieku sodišana; 3) upuru reabilitācija un kompensācijas piešksiršana; 4) publisko amatpersonu lustrācija un liegums bijušajiem režīma funkcionāriem strādāt demokrātiskas valsts pārvaldes amatos. ${ }^{17}$

Vēl pirms ANO pievēršanās pārejas taisnīguma jautājumiem 20. gadsimta nogalē Vācijā neilgi pēc Otrā pasaules kara saistībā ar nacionālsociālistiskā režīma laikā pastrādāto noziegumu izvērtēšanu izmantots jēdziens "vēstures pārvarēšana" (vācu val. - Aufarbeitung der Vergangenheit). ${ }^{18}$ Latviešu valodā šo jēdzienu lietojis arī E. Levits, runājot par nepieciešamību izvērtēt iepriekšèjos nedemokrātiskos režīmus. ${ }^{19}$ Latviešu valodā vārds "pārvarēšana" pat ḷoti precīzi atspoguḷo pārejas taisnīguma ideju. Latviešu literārās valodas vārdnīcā skaidrots, ka pārvarēt nozīmē ar aktīvu darbību panākt, ka tas, kas ir nevēlams, sabiedrībā mazinās, mainās, zūd un nespēj kavēt kā attīstību. ${ }^{20}$ Tātad pagātnes netaisnību pārvarēšana jāsaprot kā aktīva (valsts un pašas sabiedrības) rīcība, lai netaisnība sabiedrībā pazustu, tas ir, netaisnība ir jānolīdzina (caur sodu un reparācijām).

14 Transitional Justice and Economic, Social and Cultural Rights. The Office of the High Commissioner for Human Rights, 2014. Pieejams: https://www.ohchr.org/Documents/Publications/HR-PUB-13-05. pdf [aplūkots 22.02.2019.].

15 The rule of law and transitional justice in conflict and post-conflict societies. Report of the SecretaryGeneral, 23 August 2004, 8. punkts. Pieejams: https://www.un.org/ruleoflaw/files/2004\%20report.pdf [aplūkots 22.02.2019.].

16 Transitional Justice and Economic, Social and Cultural Rights. The Office of the High Commissioner for Human Rights, 2014, p. 5. Pieejams: https://www.ohchr.org/Documents/Publications/HRPUB-13-05.pdf [aplūkots 22.02.2019.].

17 Levits E. Pagātnes pārvarēšana. Grām.: Levits E. Valstsgriba. Rīga: Latvijas Vēstnesis, 2019, 668. lpp.

18 Schulz-Hageleit P. Aufarbeitung der Vergangenheit. In: Geschichtsbewusstsein und Zukunftssorge. Geschichte und Psychologie, 2004, Vol. 12. Centaurus Verlag \& Media, Herbolzheim, S. 57. Pieejams: https://datubazes.lanet.lv:5301/chapter/10.1007/978-3-86226-409-4_5 [aplūkots 31.03.2019.].

19 Levits E. Pagātnes pārvarēšana. 2019, 667.-677. lpp.

20 Šḳirklis "pārvarēt”. Latviešu literārās valodas vārdnīca. 1.-8. Rīga: Zinātne, 1972.-1996. Pieejams: http://tezaurs.lv/\#/sv/p\%C4\%81rvar\%C4\%93t [aplūkots 31.03.2019.]. 
Mērķis ir panākt, ka pagātnes netaisnības vairs nekavētu sabiedrības un valsts pilnveidi, proti, demokrātiskas un tiesiskas valsts izveidošanu, nostiprināšanos un pastāvēšanu.

Pagātnes pārvarēšanas mehānismi Vācijā tika attiecināti arī uz Vācijas Demokrātiskās Republikas atstāto mantojumu - Sociālistiskās vienības partijas (SED) diktatoriskā režīma rīcības izvērtēšanu. Šajā sakarā Vācijā tiek atzìti šādi pārejas taisnīguma pasākumi: 1) cilvēktiesību pārkāpumu pierādījumu dokumentēšana; 2) elites nomaiṇa; 3) tiesību pārkāpēju sodīšana; 4) atlīdzināšana upuriem; 5) sabiedrības apgaismošana (izglītošana). ${ }^{21}$

Kopš 20. gadsimta 80. gadiem pārejas taisnīguma tematikai veltīta arī virkne zinātnisku publikāciju kā politikas zinātnē, tā tiesību zinātnē. Viena no atzītām autoritātēm šajā jomā ir N̦ujorkas Universitātes Juridiskās skolas salīdzināmo tiesību profesore Ruti Dž. Teitela (Ruti G. Teitel, dz. 1956). Raksturojot taisnīguma nozīmi politisko pārmaiṇu laikā, viṇa secina, ka tiesības nonāk spriedzē starp pagātni un nākotni, starp retrospekciju un perspektīvu, starp individuālo un sabiedrisko. Pārejas laika tiesības ir dinamiskas tiesības, kas ar grūtībām spēj pildìt vienu no būtiskām tiesību sociālajām funkcijām - stabilitātes nodrošināšanu. Tādēl pārejas taisnīguma jēdziens ir kontekstuāls un partejisks - tas veidojas kā atbilde uz iepriekšējām netaisnībām. ${ }^{22} \mathrm{R}$. Teitela savā pārejas taisnīguma jēdzienam veltītajā monogrāfijā izvērš piecus pārejas taisnīguma elementus: krimināltiesisko taisnīgumu (vainīgo sodīšana), vēsturisko taisnīgumu (patiesības noskaidrošana), nolīdzinošo taisnīgumu (reparācijas), administratīvo taisnīgumu (lustrācija) un konstitucionālo taisnīgumu. Profesore apgalvo, ka fundamentālu politisko pārkārtojumu periodos ideālās taisnīguma teorijas nav labākais kritērijs, ko izmantot, vērtējot juridiskas rīcības pareizību. R. Teitela, izmantojot induktīvu pieeju un analizējot pārejas taisnīguma izpausmes vēsturiskā un salīdzinošā perspektīvā, atklāj neideālu, "kompromitētu" taisnīgumu, kas ir atkarīgs no apstākḷiem, kuros tas ticis ieviests. ${ }^{23}$ Ja pārejas taisnīguma mehānismi ir efektīvi, ar laiku izzūd nepieciešamība pēc šādiem ekstraordināriem mehānismiem un tie pakāpeniski var tikt atcelti.

Pārejas taisnīguma mehānismu pārejošais jeb pagaidu raksturs atklājas arī Satversmes tiesas judikatūrā - 2018. gada 29. jūnija spriedumā lietā Nr. 2017-25-01 "Par Saeimas vēlēšanu likuma 5. panta 6. punkta atbilstību Latvijas Republikas Satversmes 1., 9. un 91. pantam” tiesa norādijusi, ka šāds pamattiesību ierobežojums var pastāvēt tikai noteiktu laiku, tādēḷ likumdevējam, periodiski izvērtējot politisko situāciju valstī, jālemj par šāda ierobežojuma nepieciešamību un pamatotību. ${ }^{24}$ Arī Eiropas Cilvēktiesību tiesa 2006. gada 16. marta spriedumā lietā “Ždanoka pret Latviju” norādījusi, ka Latvijas parlamentam ir pastāvīgi jāpārskata apstrīdētajā normā noteiktais ierobežojums ar mērķi to drīzumā atcelt. Tiesa arī piebildusi, ka, ņemot vērā patlaban Latvijā pastāvošo stabilitātes līmeni un sakarā ar tās pilnīgu integrāciju Eiropā Latvijas likumdevējvaras nespēja veikt aktīvus pasākumus šajā ziṇā var novest pie citāda konstatējuma. ${ }^{25}$ Šāds Eiropas

${ }^{21}$ Kellerhoff S. F. Aus der Geschichte lernen. Ein Handbuch zur Aufarbeitung von Diktaturen. BadenBaden: Nomos, 2013.

22 Teitel R. G. 2001, pp. 6-9.

${ }^{23}$ Ibid., p. 227.

${ }^{24}$ Satversmes tiesas 29.06.2018. spriedums lietā Nr. 2017-25-01, secinājumu daḷas 24.1. punkts.

25 ECT 16.03.2006. spriedums lietā Ždanoka pret Latviju (iesniegums Nr. 58278/00), Latvijas Republikas Ārlietu ministrijas tulkojums, 135. punkts. 
Cilvēktiesību tiesas aizrādījums uzsver nepieciešamību pārejas taisnīguma mehānismus aplūkot dinamiski. Tomēr striktas laika robežas vai pat konkrētu noilguma termiņu pārejas taisnīguma mehānismu piemērošanai liedz noteikt šī koncepta kontekstuālais un partejiskais raksturs. Autore uzskata, ka gadījumā, ja visi pārejas taisnīguma mehānismi (elementi) tiktu aplūkoti un īstenoti kā vienota sistēma, tad pagātnes pārvarēšana norisinātos efektīvāk un ar to saistītie pamattiesību ierobežojumi vairs nebūtu tik ilgstoši nepieciešami. Šāda sistēmiska pieeja l̦autu kāda viena pārejas taisnīguma mehānisma trūkumus vismaz zināmā mērā kompensēt ar citu instrumentu, tādējādi sekmējot izlīguma panākšanu sabiedrībā un vēsturisko netaisnību pārvarēšanu. Piemēram, ja vairs nav iespējams krimināltiesiskā kārtā novērtēt kādas personas vainu nozieguma izdarīšanā vai vinụu sodīt, tad lielāka uzmanība būtu jāpievērš patiesības atklāšanai un sabiedriskās domas veidošanai.

\section{Pārejas taisnīguma nozīme tiesību piemērošanā}

Lai arī pārejas taisnīguma īstenošana primāri ir likumdevēja uzdevums, taisnīguma kā vispārējā tiesību principa atzī̌sana neizbēgami liek arī tiesu varai iesaistīties pagātnes pārvarēšanas mehānismu ieviešanā. Pārejas taisnīguma koncepts ir jāṇem vērā arī tiesību normu piemērošanā, iztulkojot tiesību normas (domājams, pēc sistēmiskās vai teleolog̣iskās interpretācijas metodes).

Pārejas taisnīguma kā dažādu mehānismu kopuma perspektīva liek citā gaismā skatīties uz vārda brīvības saturu un juridiskās atbildības piemērošanas priekšnosacījumiem neslavas celšanas vai godu aizskarošu ziṇu izplatǐšanas gadījumā. Pašlaik judikatūrā ir nostiprinājusies atziṇa, ka pat ar viedokli nedrīkst pārkāpt nevainīguma prezumpciju un apsūdzēt krimināli sodāmu darbību izdarī̌anā. Atzinums noziedzīga nodarījuma izdarǐšanā nedrīkst būt izteikts nekādā formā, ja to nav konstatējušas kompetentās tiesību sargājošās institūcijas. ${ }^{26}$ Taču, ja pāridarītājus vairs nav iespējams krimināltiesiski sodīt, ja viṇu vārdus un nodarījumus nedrīkst nosodīt pat vārdos, vai ir iespējama pagātnes pārvarēšana, vai ir novērsta nesodāmība un vai tiešām ir darìts viss iespējamais, lai nākotnē pagātnes noziegumi vairs neatkārtotos? Līdz ar to vārda brīvības izmantošanai pārejas taisnīguma mehānismu ietvaros būtu nosakāms augstāks tolerances slieksnis. Vācijas Federālā Konstitucionālā tiesa, vērtējot vārda brīvības un personības tiesību kolīziju, kas radusies pēc VDR Valsts drošỉbas ministrijas neoficiālo darbinieku saraksta publicēšanas, norādīja, ka vēstures pārvarēšana ir vārda brīvības ietvarā aizsargājama rīcība. ${ }^{27}$

Tartu Universitātes politikas zinātnieki Vello Petai (Vello Pettai) un Eva Klarita Petai (Eva-Clarita Pettai), pētot pārejas taisnīguma mehānismus Baltijā, kā pamatprincipu dažādu taisnības un patiesības politikas pasākumu klasificēšanai izmanto šo konkrēto pasākumu adresātu (mērḳi). Tādējādi kāds konkrēts pārejas taisnīguma instruments var būt orientēts uz pārkāpējiem (viṇu identificēšana,

${ }^{26}$ Markvarts R. Goda un cieņas civiltiesiskā aizsardzība. Tiesu prakses apkopojums (2000-2018). Rīga, 2019, 10.-11. lpp. Pieejams: http://www.at.gov.lv/lv/jaunumi/par-notikumiem/apkopota-tiesu-prakselietas-par-goda-un-cienas-civiltiesisko-aizsardzibu-9444 [aplūkots 22.02.2019.].

${ }^{27}$ BVerfG, Beschluss der 1. Kammer des Ersten Senats vom 23. Februar 2000 - 1 BvR 1582/94 - Rn. (1-39). Pieejams: https://www.bundesverfassungsgericht.de/e/rk20000223_1bvr158294.html [aplūkots 31.03.2019.]. 
sodīšana, tiesību ierobežošana u. tml.) vai uz upuriem (reabilitācija, kompensāciju piešķiršana). ${ }^{28}$ Lai pārejas taisnīguma mehānismi būtu taisnīgi un sasniegtu savu mērḳi (garantētu arī turpmāku demokrātiskas un tiesiskas valsts pastāvēšanu), likumdevējam jāspēj nodrošināt līdzsvars starp pārkāpēju sodīšanu (kaut vai tikai simbolisku nosodījumu) un cietušajām personām nodarītās netaisnības atlīdzināšanu.

Galvenais pārejas taisnīguma mehānisms, kas vērsts uz cietušajiem nodarītās netaisnības izlīdzināšanu Latvijā, ir nelikumīgi represēto personu reabilitācija un politiski represētās personas statusa noteikšana. Likums "Par nelikumīgi represēto personu reabilitāciju" nekonkretizē reabilitācijas jēdziena nozīmi un neuzskaita nelikumīgi represēto personu subjektīvās tiesības. ${ }^{29}$ Krimināltiesību kontekstā reabilitācija primāri tiek skaidrota kā personas atzišana par nelikumīgi sodītu un līdz ar to nevainīgu. Reabilitācija ir personas atjaunošana tiesībās, personas labā vārda un iepriekšējās reputācijas atjaunošana. Kā uzsvērusi Augstākā tiesa, reabilitācija ir sarežgìtākais veids, kādā persona var izbeigt kriminālatbildības tiesiskās sekas. ${ }^{30}$ Tulkojot reabilitācijas jēdzienu sistēmiski ar politiski represētās personas statusu, redzams, ka reabilitācijas institūts izmantojams plašāk - ne tikai kriminālatbildības negatīvo seku novēršanai, bet vispār komunistiskā totalitārā režīma nodarīto tiesību pārkāpumu radīto seku mazināšanai. Reabilitācija tiek attiecināta arī uz citām personu kategorijām, piemēram, personām, kurām piemēroti medicīniska rakstura piespiedu līdzekḷi, personām, kas izsūtītas, nometinātas vai pārvietotas no pastāvīgās dzīvesvietas, dzimušas izsūtījumā vai nometinājumā.

Likums "Par politiski represētās personas statusa noteikšanu komunistiskajā un nacistiskajā režīmā cietušajiem" noteic, ka politiski represēto personu tiesības garantē valsts. ${ }^{31}$ Satversmes tiesa ir skaidrojusi, ka šì likuma primārais un galvenais mērḳis ir taisnīgums, tā nodrošināšana. Likumdevēja mērḳis bijis taisnīga tiesību atjaunošana atbilstoši likumam tām personām, kuras ir cietušas no represijām komunistiskajā un nacistiskajā režīmā. ${ }^{32}$ Kā subjektìva tiesība likuma "Par politiski represētās personas statusa noteikšanu komunistiskajā un nacistiskajā režìmā cietušajiem" 9. panta otrajā daḷā ir formulētas politiski represēto personu tiesības saṇemt kompensāciju, dzēšot par atņemto mantu piešķirtos īpašuma kompensācijas sertifikātus. Taču citas ar politiski represētās personas statusu saistītās tiesības formulētas kā valsts uzdevumi, piemēram, valsts nodrošina politiski represēto personu likteņu vēsturisku izpēti; valsts nodrošina politiski represēto personu tiesību atjaunošanu civilo, ekonomisko un sociālo tiesību sfērā atbilstoši likumam; valsts un pašvaldību institūcijas un to amatpersonas pēc politiski represēto personu, kā arī citu ieinteresēto personu iesniegumu saṇemšanas gādā, lai likumā noteiktajā kārtībā tiktu novērstas totalitāro režīmu radīto civilo, ekonomisko un sociālo tiesību ierobežojumu izraisītās sekas, atlīdzināti šo režīmu radītie materiālie zaudējumi, to nodarītais fiziskais un morālais kaitējums.

\footnotetext{
28 Pettai E.-C., Pettai V. Transitional and Retrospective Justice in the Baltic. Cambridge: Cambridge University Press, 2015, p. 312.

${ }^{29}$ Likums "Par nelikumīgi represēto personu reabilitāciju“: LV likums. Pieņemts 03.08.1990. [31.03.2019.].

${ }^{30}$ Latvijas Republikas Augstākās tiesas Senāta Civillietu departamenta 05.10.2011. spriedums lietā Nr. SKC-478/2011, 12.1. punkts.

31 Likums "Par politiski represētās personas statusa noteikšanu komunistiskajā un nacistiskajā režīmā cietušajiem": LV likums. Pieņemts 12.04.1995. [31.03.2019.].

32 Satversmes tiesas 20.04.1999. spriedums lietā Nr.04-01(99), 1.3. punkts.
} 
Īstenojot reabilitācijas politiku, Latvijas likumdevējs sevišķ ku akcentu ir licis uz mantisko tiesību atjaunošanu un mantiska rakstura atlīdzinājumu piešķiršanu (atvieglojumi nodokḷu un nodevu maksāšanā, atvieglojumi pensijas piešķiršanā, bezmaksas medicīniskā aprūpe, sociālā rehabilitācija un atvieglojumi sabiedriskā transporta izmantošanā). Taču šāda pieeja nevar tikt uzskatìta par visaptverošu pārejas taisnīguma kontekstā - ne attiecībā uz cietušo personu loku, ne pienākumu izlīdzināt netaisnību vai novērst līdzīgu netaisnību atkārtošanos. Vācu tiesību zinātnieks Alberts Engels (Albert Engel) savā disertācijā, kas veltìta VDR Valsts drošības dienestu darbības tiesiskai izvērtěšanai, uzsver, ka represīva režīma upuri pienācīgu gandarījumu var saņemt tikai tad, ja reabilitācija tiek izprasta pietiekami plaši - kā politiski morāla cietušo gandarīšana un materiāla atlīdzināšana vienlaikus. Ja represīvā režìma drošîbas dienestu rīcība nevar tikt pakḷauta tiesu jurisdikcijai, tā būtu nododama valsts ceturtās varas izvērtējumam un atklātībai. Tādējādi vēl arvien būtu iespējams nodrošināt vēsturisko netaisnību pārvarēšanu un upuru gandarišanu. ${ }^{33}$

Reabilitācijas ideja un politiski represētas personas statuss ir valsts atbilde uz pagātnē pastrādātu tiesību pārkāpumu - netaisnību. Taču tiesību pārkāpums savā būtībā ir cilvēka nepareiza rīcỉba, nevis dabisks notikums, kas atrodas ārpus cilvēka ietekmes. Tāpēc reakcija uz netaisnīgu rīcību nedrīkst aptvert tikai cietušo, bet tai ir jābūt vērstai arī pret vainīgo personu. Soda ideja neaprobežojas tikai ar restitūciju, tādēl arī politiski represēto personu tiesību atjaunošana, nodarìto zaudējumu un kaitējuma atlīdzināšana nedrīkst būt vienīgie istenotie pārejas taisnīguma instrumenti. Vērtējot uz vainīgajiem jeb pārkāpējiem vērstos pārejas taisnīguma mehānismus, var secināt, ka tie aptvēruši salīdzinoši mazāku personu loku un šaurāku sabiedrisko attiecību lauku (pārsvarā tie ir bijuši politisko tiesību ierobežojumi). Līdz ar to var runāt par zināmu disproporciju pārejas taisnīguma îstenošanā. Ja krimināltiesiskā ceḷā konkrētu personu vaina vairs nevar tikt noskaidrota vai arī viņas vairs nevar tikt sodìtas, valsts pienākums atjaunot taisnīgumu, novērst nesodāmību un necilvēcīgu noziegumu atkārtošanos nākotnē neizbeidzas. Taisnigums nevar tikt reducēts tikai uz krimināltiesībām, tas ir visu tiesību sistēmu caurvijoša vērtība un ētisks princips, kas jārespektē kā politisku lēmumu pieṇemšanā, tā arī tiesību piemērošanā.

Saskaṇā ar ANO atzīto pārejas taisnīguma izpratni vēstures pārvarēšana nevar notikt bez izlīguma panākšanas. Kā skaidrojis E. Levits, izlīgumu kā sociālpsihologiisku kategoriju var panākt tikai tad, ja noteiktas darbïbas veic gan upuris, gan vainīgais (netaisnības nodarītājs). Patiesības noskaidrošana kā pirmais uzdevums ir jāveic gan cietušajam, gan vainīgajam. Taču tālākie izlīgumam nepieciešamie soḷi - nodarījuma atzišsana, nožělošana un izpirkšana ar kādu pozitīvu rīcību jāsper vainīgajam. Tikai tad var sekot piedošana no cietušā puses un patiess abu pušu izlīgums. ${ }^{34}$ Pārejas taisnīgums kā taisnīguma principa konkretizējums tiesiskās iekārtas transformācijas periodos būtu jāīsteno arī tiesām, lai pēc iespējas drīzāk Latvijas sabiedrība spētu pārvarēt totalitāro režìmu nodarìto netaisnību.

\footnotetext{
${ }^{33}$ Engel A. Die rechtliche Aufarbeitung der Stasi-Unterlagen auf der Grundlage des StUG. Berlin: Duncker \& Humblot, 1995, S. 346, 347, 351, 368.

${ }^{34}$ Levits E. Pagātnes pārvarēšana. 2019, 668.-669. lpp.
} 


\section{Kopsavilkums}

1. Latvijas tiesiskās iekārtas pārveidošana pēc neatkarības atjaunošanas uzskatāma par pāreju no komunistiskā totalitārā režīma uz demokrātisku. Šāda veida transformācija ietver nepieciešamību apzināties un izvērtēt pagātnes netaisnības un pastrādātos noziegumus un turpmāk attīstìt tiesisko iekārtu saskaṇā ar demokrātiskas un tiesiskas valsts principiem. Politikas teorijā un tiesību zinātnē šādu transformācijas procesu raksturošanai un izpratnei tiek izmantots pārejas taisnīguma jēdziens (transitional justice). Vācijā šādā kontekstā tiek lietots vēstures pārvarēšanas jēdziens (Aufarbeitung der Vergangenheit).

2. ANO sistēmā pārejas taisnīgums tiek saprasts kā dažādu procesu un mehānismu kopums, kas saistīts ar sabiedrības mēǵinājumiem pārvarēt pagātnē notikušos liela mēroga tiesību pārkāpumus, lai nodrošinātu atbildību, kalpotu taisnīgumam un panāktu izlīgumu. Viens no galvenajiem pārejas taisnīguma mehānismu ieviešanas uzdevumiem ir novērst nesodāmību.

3. Salīdzināmo tiesību profesore Ruti Dž. Teitela skaidro, ka pārejas taisnīguma jēdziens ir kontekstuāls un partejisks, jo tas veidojas kā atbilde uz iepriekšējām netaisnībām. Pārejas taisnīgums kā tiesisks mehānisms ietver krimināltiesisko taisnīgumu (vainīgo sodīšana), vēsturisko taisnīgumu (patiesības noskaidrošana), nolīdzinošo taisnīgumu (reparācijas), administratīvo taisnīgumu (lustrācija) un konstitucionālo taisnīgumu.

4. Pārejas taisnīguma pasākumiem piemīt pagaidu raksturs, un tie ir aplūkojami dinamiski. Lai pagātnes pārvarēšana norisinātos efektīvāk un ar to saistītie pamattiesību ierobežojumi nebūtu jāpiemēro ilgstoši, nepieciešams visus pārejas taisnīguma instrumentus uztvert un ìstenot kā vienotu sistēmu. Sistēmiska pieeja ḷautu kāda viena pārejas taisnīguma mehānisma trūkumus zināmā mērā kompensēt ar citu instrumentu.

5. Lai arī pārejas taisnīguma īstenošana primāri ir likumdevēja uzdevums, taisnīguma kā vispārēja tiesību principa atzī̌ana neizbēgami liek arī tiesu varai iesaistīties pagātnes pārvarēšanas mehānismu efektīvā ieviešanā. Pārejas taisnīguma koncepts ir jāṇem vērā arī tiesību normu piemērošanā, iztulkojot tiesību normas (sistēmiskās vai teleoloǵiskās interpretācijas metodes ietvaros) un risinot pamattiesību kolizijas. 